\title{
$\beta$-globin variants present in Western Sudan
}

\begin{abstract}
Objective: A variety of observations of the hemoglobin D ( $\mathrm{Hgb} \mathrm{D}$ ) phenotype has occurred in association with family studies of patients with sickle cell disease. Very little is known about the occurrence and prevalence of the Hgb D variant and its impact on blood profiles among Sudanese. This study was aimed at determining the percentage of $\mathrm{Hb} \mathrm{D}$ in North Darfur State, West Sudan, whose population has been shown to have hemoglobin-S (Hb S) disease.

Methods: From December 2017 to August 2018, this descriptive community-based investigation was conducted. Six hundred and sixty-six (666) people were randomly selected to participate in this study. With each participant's there was verbal consent. A questionnaire was designed to collect personal details. $5 \mathrm{~mL}$ of venous blood was gathered in EDTA containers. The Hb D variant was checked using Sebia Minicap Automated Capillary Electrophoresis System- USA and frequency was calculated using version 21.0 of the software package for social science (SPSS).
\end{abstract}

Result: The prevalence of $\mathrm{Hb}$ variants was as follows: $\mathrm{AD}=0.6 \%, \mathrm{SS}=2 \%, \mathrm{AS}=10.5 \%$, and $\mathrm{AA}=86.9 \%$.

Conclusion: The prevalence of $\mathrm{Hb} \mathrm{D}$ variant was $4(0.6 \%)$ in 666 participants from four western Sudanese tribes, beside reported of $\mathrm{Hb} \mathrm{SS}$ and $\mathrm{Hb} \mathrm{AS}$.

Keywords: $\mathrm{Hb}$ variants, $\mathrm{HbD}$, north Darfur, Sudan

\author{
Volume 9 Issue 3 - 202I
}

\begin{abstract}
Nahla Ahmed Mohammed Abderahman,' Nassreldeen Khalid Abdelrahman Adam, ${ }^{2}$ Mohammed Ahmed Ibrahim Ahmed ${ }^{3}$

'Assistant professor of Biochemistry, Faculty of Medicine, Department of Biochemistry, Nile Valley University- Atbara, Sudan

${ }^{2}$ Assistant professor of hematology, Faculty of Medical Laboratory Science, University of Al Fashir, Sudan ${ }^{3}$ Assistant professor of Microbiology, Faculty of Medicine, Department of Microbiology, Nile Valley University- Atbara, Sudan
\end{abstract}

Correspondence: Dr. Nahla Ahmed Mohammed Abdurrahman, Assistant professor of Biochemistry, Nile Valley University, Faculty of Medicine- Atbara, Sudan, Tel +249|23590647, Emailnahlaharazawy@ymail.com, nahlaharazawy@gmail.com

Received: May 2I, 202I | Published: June 30, 202I
Abbreviations: $\mathrm{NN}$, normal $\mathrm{Hb}$; $\mathrm{AS}$, heterozygote of hemoglobin S; SS, homozygote of hemoglobin S; DD, homozygote of hemoglobin $\mathrm{D} ; \mathrm{AD}$, heterozygote of hemoglobin $\mathrm{D}$

\section{Introduction}

Hemoglobin $(\mathrm{Hb})$ is a tetrameric protein made up of two alpha $(\alpha)$ and two beta $(ß)$ globin chains with heme as a prosthetic group. Its principal function is to carry oxygen to the tissues and return $\mathrm{CO}_{2}$ to the lungs. Adult hemoglobin ( $\mathrm{Hb} \mathrm{A}$ ) is the most common type, with two $\alpha$ and two $\beta$ chains. The most common type of hemoglobin found at birth is fetal hemoglobin ( $\mathrm{Hb} \mathrm{F}$ ), which is made up of two $\alpha$ and two $\gamma$ chains. ${ }^{1}$

Approximately $7 \%$ of the world's population has mutations in genes that code for hemoglobin chains. These genetic mutations can affect the outcome at which globin chains are formed, triggering thalassemia, or they can change the composition of the molecule, resulting in hemoglobin variants. ${ }^{2}$ Hemoglobin variants are generally the result of single amino acid substitutions induced by point mutations in globin chain genes, ending in a tetramer of various physicochemical properties. ${ }^{3}$ The globin Gene Server database (http:// globin.cse.psu.edu/) contained 1198 hemoglobin variants before September 2014. The majority of the hemoglobin variants listed may not elicit symptomatic clinical manifestations; but, in certain circumstances, such as Sickle cell hemoglobin, they can be linked to relevant pathophysiology. $\mathrm{Hb} \mathrm{S}$ is the most frequent hemoglobin variant in the world; its clinical outcome is severe in homozygous or in association with other relatively common hemoglobinopathies, such as beta-thalassemia, $\mathrm{Hb} \mathrm{C}$ or $\mathrm{Hb} \mathrm{D.}{ }^{4}$ The most common pathological $\mathrm{Hb}$ variants worldwide in descending order of prevalence are $\mathrm{Hb} \mathrm{S}$, $\mathrm{HbE}, \mathrm{HbC}$, and $\mathrm{Hb} \mathrm{D}$. All of these hemoglobins have single amino acid substitutions in the $\beta$ chain. At position 6 of the $\beta$ chain, $\mathrm{Hb} S$ has a valine instead of glutamic acid and in the similar position $\mathrm{Hb}$
$\mathrm{C}$ had a mutation in glutamic acid instead of lysine. At position 26 of the $\beta$ chain, lysine is replaced for glutamic acid in $\mathrm{Hb} \mathrm{E}$. Additionally, in $\mathrm{Hb} \mathrm{D}$, glutamine is substituted for glutamic acid at position 121 of the $\beta$-globin chain, ${ }^{5}$ resulting in $\mathrm{Hb} \mathrm{D}$ disease which is an autosomal recessive condition consequential in mild hemolytic anemia. The heterozygous variant $(\mathrm{Hb} \mathrm{AD})$ is more popular than the homozygous type (Hb DD), which is uncommon. ${ }^{6}$

\section{Materials and methods}

Between December 2017 and August 2018, a cross-sectional, prospective community-based study was implemented in Northern Darfur. The aim of the study was to figure out which $\mathrm{Hb}$ variants existed in North Darfur. Six hundred and sixty-six (666) people were randomly selected from all parts of north Darfur after granting their informed consent, with represent of all the major Northern Darfur tribal communities. Direct structural interviewing and a questionnaire were used to gather information. Demographic details such as age, sex, ethnicity (tribe), and family history were recorded. The State Ministry of Health approved ethical clearance. Sebia Minicap Automated Capillary Electrophoresis System- USA was used to identify $\mathrm{Hb}$ variants in five $\mathrm{mL}$ of venous blood (with K2-EDTA) from each respondent

\section{Results}

Six hundred and sixty-six individuals were participating in the present study, with an average age of 21.3 years. Of these $55 \%$ were females with an average age of $21.7 \pm 18.3$ years and the remaining $45 \%$ were male with an average age of $20.9 \pm 15.4$ years (Table 1 ). The respondents came from different tribal groups, who constitute the majority of the Northern Darfur tribes (Table 2). The study showed the prevalence of $\mathrm{Hb}$ variants $\mathrm{AA} ; 86.9 \%$; $\mathrm{Hb} \mathrm{SS}=2 \%$; $\mathrm{Hb} \mathrm{AS}=10.5 \%$ and $\mathrm{Hb} \mathrm{AD}=0.6 \%$. 
Table I Gender and average age of the research group

\begin{tabular}{llll}
\hline Gender & Frequency & Percent \% & Mean age (years) \\
\hline Male & 297 & 45 & $20.9 \pm 15.4$ \\
Female & 369 & 55 & $21.7 \pm 18.3$ \\
Total & 666 & 100 & - \\
\hline
\end{tabular}

Table 2 Percentage of $\mathrm{Hb}$ variants in the research group

\begin{tabular}{|c|c|c|c|c|c|c|c|c|c|}
\hline \multirow[b]{3}{*}{ Locality } & \multicolumn{9}{|c|}{ Hemoglobin variants } \\
\hline & \multirow[b]{2}{*}{ Total } & \multicolumn{2}{|l|}{ AA } & \multicolumn{2}{|l|}{ AS } & \multicolumn{2}{|l|}{ ss } & \multicolumn{2}{|l|}{$A D$} \\
\hline & & Frequency & $\%$ & Frequency & $\%$ & Frequency & $\%$ & Frequency & $\%$ \\
\hline ALFASHER & 195 & 160 & 82.1 & 26 & 13.3 & 6 & 3.1 & 3 & 1.54 \\
\hline SARF-OMR & 15 & 13 & 86.7 & 2 & 13.3 & 0 & 0 & 0 & 0 \\
\hline KALMENDO & 15 & 13 & 86.7 & 2 & 13.3 & 0 & 0 & 0 & 0 \\
\hline ALMALHA & 17 & 17 & 100 & 0 & 0 & 0 & 0 & 0 & 0 \\
\hline ALKOMA & 19 & 14 & 73.7 & 3 & 15.7 & 1 & 5.3 & 1 & 5.3 \\
\hline OMBARO & 26 & 25 & 96.2 & 1 & 3.8 & 0 & 0 & 0 & 0 \\
\hline ALTEWSHA & 12 & 8 & 66.7 & 3 & 25 & 1 & 8.3 & 0 & 0 \\
\hline ALWAHA & 33 & 30 & 90.9 & 3 & 9.1 & 0 & 0 & 0 & 0 \\
\hline UM-KADAD & 14 & 14 & 100 & 0 & 0 & 0 & 0 & 0 & 0 \\
\hline ALLAYEED & 33 & 33 & 100 & 0 & 0 & 0 & 0 & 0 & 0 \\
\hline ALSERAF & 21 & 20 & 95.2 & I & 4.8 & 0 & 0 & 0 & 0 \\
\hline DAR-ALslam & 41 & 27 & 65.9 & 11 & 26.8 & 3 & 7.3 & 0 & 0 \\
\hline TAWELA & 56 & 49 & 87.5 & 7 & 12.5 & 0 & 0 & 0 & 0 \\
\hline KUTOM & 40 & 38 & 95 & 2 & 5 & 0 & 0 & 0 & 0 \\
\hline MALET & 17 & 17 & 100 & 0 & 0 & 0 & 0 & 0 & 0 \\
\hline KORMA & 52 & 47 & 90.4 & 5 & 9.6 & 0 & 0 & 0 & 0 \\
\hline KABKABYA & 10 & 9 & 90 & 1 & 10 & 0 & 0 & 0 & 0 \\
\hline ALTENA & 33 & 30 & 90.9 & 3 & 9.1 & 0 & 0 & 0 & 0 \\
\hline KARNOY & 17 & 15 & 88 & 0 & 0 & 2 & 12 & 0 & 0 \\
\hline Total & 666 & 579 & 86.9 & 70 & 10.5 & 13 & 2 & 4 & 0.6 \\
\hline
\end{tabular}

\section{Discussion}

$\mathrm{HbD}$ - known as Punjab or Los Angeles - is underexplored, especially in Sudan, where this recent study about its prevalence was carried out. Moreover, $\mathrm{Hb} \mathrm{D}$ presents in considerable geographic distribution and is associated with $\mathrm{Hb} \mathrm{S}$, forming a heterozygous composite with peculiar clinical severity. Allocation of Hb D-Punjab in Punjab region, Northwest Indian and Gujarat region with an estimated frequency of $2.0 \% .^{7}$ Globally $\mathrm{Hb} \mathrm{D}$ is occurs in variety of countries include Italy, ${ }^{8}$ Turkey, ${ }^{9}$ Belgium, ${ }^{10}$ Austria, ${ }^{11}$ Xinjiang province, northwestern China, ${ }^{12,13}$ Caucasian individuals in England and the United States, ${ }^{6}$ British family of Spanish and Austrian extraction, ${ }^{14}$ a mulatto child of an English mother ${ }^{15}$ and in the American Indian. ${ }^{16}$ The percentage of worldwide prevalence of $\mathrm{Hgb} \mathrm{D}$ was recorded in the American Negro $0.4 \%$, the Algerian Moslems 2.0\% and Sikhs of North-Central India 2.0. ${ }^{17}$
In our current study $83(12.5 \%)$ of participants had the genotype $\mathrm{Hb} \mathrm{SS}$ and $\mathrm{Hb}$ AS, from these cases, 70 (10.51\%) had the AS gene and the remaining $13(1.95 \%)$ had the SS gene. $4(0.6 \%)$ had $\mathrm{Hb} \mathrm{AD}$ in four tribes of Northern Darfur state. This abnormality was the first time to be recorded in Northern Darfur state combined with prevalence of $\mathrm{Hb}$ SS and $\mathrm{Hb}$ AS. Gibreel et al. ${ }^{18}$ reported that 2 (3.39\%) \% with $\mathrm{Hb}$ D and 12 (20.34\%) showed patterns consistent with sickle cell disease (SS) of 209 participants in Eastern Beja tribes- Sudan; this with our resent study indicating that Sudan is a diverse country with a complex population originating from different ethnic groups created from intermarriage and social interaction status. The most important discover was that a number of reports of the $\mathrm{Hb} \mathrm{D}$ trait have appeared in connection with family studies of patients with sickle cell- $\mathrm{Hb}$ SS disease $^{6,14}$ which was in line with our current study. 


\section{Conclusion}

The prevalence of $\mathrm{HbD}$ variant was $4(0.6 \%)$ in 666 participants from four western Sudanese tribes, beside reported of $\mathrm{Hb} \mathrm{SS}$ and $\mathrm{Hb}$ AS.

\section{Recommendations}

Further exploration into $\mathrm{Hb} \mathrm{D}$ variants in Sudan is needed to understand the various forms of $\mathrm{Hb}$ variants in diverse ethnic and locations.

\section{Acknowledgments}

Best wishes and appreciation to the Hematology Department staff at Sudan University of Science and Technology (SUST), Alneelain University- Faculty of Medicine, Medical Research Centre, Tropical Medicine Research Institute, Alafia medical complex and El Fasher University for their co-operation and acceptance to do the research there.

\section{Conflicts of interest}

The authors declare no conflicts of interest.

\section{References}

1. Taliaferro H, Huck JG. The inheritance of sickle cell anemia in man Genetics Soc America. 1923;8(6):594-598.

2. Weatherall DJ, Clegg JB. Inherited haemoglobin disorders: anincreasing global health problem. Bull World Health Organ. 2001;79(8):704-712.

3. Thom CS, Dickson CF, Gell DA, et al. Hemoglobin variants: biochemical properties and clinical correlates. Cold Spring Harb Perspect Med. 2013;3(3):a011858

4. Frenette P, Atweh G. Sickle cell disease: old discoveries, newconcepts, and future promise. J Clin Invest. 2007;117(4):850-858.

5. Modell B, Darlison M. Global epidemiology of haemoglobin disorders and derived service indicators. Bull World Health Organ. 2008;86(6):480 487.
6. Itano H. Third abnormal hemoglobin associated with hereditary hemolytic anemia. Proc Nat Acad Sc. 1951;37(12):775-784.

7. Köseler A, Öztürk O, Atalay A, et al. Allele frequency of VNTR locus D1S80 observed in Hb D-Los Angeles carriers. Mol Biol Rep. 2012;39(12):10747-10750.

8. Fioretti G, De Angioletti M, Pagano L, et al. DNA polymorphisms associated with $\mathrm{Hb}$ D-LosAngeles b121(GH4)Glu $\rightarrow$ Gln in Southern Italy. Hemoglobin. 1993;17(1):9-17.

9. Atala E, Koyuncu H, Turgut B, et al. High incidence of Hb D-Los Angeles 121(GH4) Glu $\rightarrow$ Glnin Denizli province Aegean region of Turkey. Hemoglobin. 2005;29(4):307-310.

10. Husquinet H, Parent M, Schoos-Barbette S, et al. Hemoglobin D-Los Angeles _ 121(GH4)Glu $\rightarrow \mathrm{Gln}$ in the province of Liege Belgium. Hemoglobin. 1986;10(6):587-592.

11. Lischka A. Pollak A; Bauer K, et al. (1984). Hemoglobin D "Los Angeles" in an Austrian family: biochemical identification, clinical aspects, and kindredstudy. Hemoglobin. 1984;8(4):353-361.

12. Li HJ, Zhao XN, Qin F, et al. Abnormal hemoglobins in the silk road region of China. Hum Genet. 1990;86(2):231-235.

13. Pandey S, Mishra RM, Pandey S, et al. Molecular characterization of hemoglobin D Punjab traits and clinical-hematological profile of the patients. Sao Paulo Med J. 2012;130(4):248-251.

14. White JC, Beaven $\mathrm{CH}$. Review of varieties of humuan hemoglobins in health and disease. J Clin Path. 1954;7:175-200.

15. Aksoy NI, Lehmann H. A further example of hemoglobin D in a Turkish family. Tr Roy Soc Trop Med \& Hyg. 1956;50:178-179.

16. Airoz IC. The Hemoglobin D Syndromes. National Institutes of Health, Bethesda. 1957.

17. Chernoff A. On the prevalence of hemoglobin D in the American Negro. Blood. 1956;11:907-909.

18. Gibreel M, Munsour M, El Yasaa A. Screening for hemoglobinipathy in Beja tribes and other minor groups living in Port Sudan City. Medical Laboratory and Diagnosis. 2014;5(4):35-40. 